\title{
Comparison of HER2 Expression in Primary Tumor and Disseminated Tumor Cells in the Bone Marrow of Breast Cancer Patients
}

\author{
Brigitte Rack $^{a} \quad$ Ewa Zombirt $^{a} \quad$ Elisabeth Trapp ${ }^{a} \quad$ Julia Jückstock ${ }^{a}$ \\ Ulrich Andergassen $^{\mathrm{a}}$ Julia Neugebauer ${ }^{\mathrm{a}}$ Bernd Kost $^{\mathrm{a}}$ \\ Tobias Weissenbacher $^{a} \quad$ Udo Jeschke $^{a} \quad$ Christian Schindlbeck $^{b}$ \\ Wolfgang Janni ${ }^{c}$ Marianna Alunni-Fabbroni ${ }^{a}$ \\ a Department of Gynecology and Obstetrics, Ludwig Maximilians University, Munich, ${ }^{\mathrm{b}}$ Department of \\ Gynecology and Obstetrics, Klinikum Traunstein, Traunstein, and ' Department of Gynecology and Obstetrics, \\ University Hospital Ulm, Ulm, Germany
}

\section{Key Words}

Breast cancer · Circulating tumor cells · Disseminated tumor cells $\cdot$ Minimal residual disease $\cdot \mathrm{HER} 2 \cdot$ Bone marrow $\cdot$

HER2-targeting agent

\section{Abstract}

Objective: The aim of this study was to measure the human epidermal growth factor receptor 2 (HER2) status of disseminated tumor cells (DTCs) from bone marrow (BM) aspirates and to assess correspondence or discrepancy with the primary tumor. Methods: DTCs were isolated from the BM of 156 breast cancer patients. Cytokeratin-positive DTCs were further analyzed by the chromogenic in situ hybridization method to detect HER2 gene amplification. Results: A significant correlation $(p=0.021)$ was found between the HER2 status of DTCs and the primary tumors. Sixty-one (68.5\%) patients had a corresponding status. However, a shift of phenotype between primary tumor and DTCs was found in the remaining patients. Conclusion: This study showed a significant grade of discordance of the HER2 status between primary tumors and DTCs in the BM of a relevant subgroup of patients. Detection of HER2 amplification on DTCs could therefore help to better stratify patients for a more tailored therapy, since they would benefit from a HER2-targeted therapy.

(c) 2016 S. Karger AG, Basel

\section{Background}

Breast cancer (BC) is the most common type of cancer diagnosed in women who have a risk of 1 in 9 to develop the disease during their lifetime [1]. According to the World Health Organization, BC is the fifth cause of death among women worldwide, being at the same time the most common cause of death due to cancer [2]. The high mortality rate observed in $\mathrm{BC}$ patients is mainly connected to the high spreading capability combined with a high tendency to form metastasis in remote organs [3, 4]. Bones are the most common targets for metastatic lesions generated by $\mathrm{BC}$ [5-7]. Unfortunately, metastatic $\mathrm{BC}(\mathrm{MBC})$ is still considered incurable, and MBC patients can only benefit from palliative therapies. Preven-

Dr. Marianna Alunni-Fabbron

Department of Gynecology and Obstetrics, Ludwig Maximilians University Maistrasse 11

DE-80377 Munich (Germany)

E-Mail Marianna.Alunni@med.uni-muenchen.de 
tion of metastasis spreading is therefore given the highest priority by the scientific and medical community in the management of primary $\mathrm{BC}$ patients. Biomedical imaging is considered the gold standard in prognosis and metastasis monitoring, being minimally invasive and very sensitive [8]. Ultrasound, positron emission tomography, computed tomography and magnetic resonance imaging are commonly used in clinical practice [9]. They estimate the extent of the disease following the spreading of the metastases, measuring their size and offering a corresponding evaluation of the response to treatment [1012]. Nevertheless, there are alternative approaches which, combined to imaging, can improve the detection efficacy. The term minimal residual disease (MRD) refers to the presence of disseminated tumor cells (DTCs) and circulating tumor cells (CTCs) in bone marrow (BM) and peripheral blood, respectively [13, 14-16]. Different studies have shown that in a high number of patients with primary BC, cytokeratin (CK)-positive DTCs can be detected in BM already at the time of the first diagnosis $[17,18]$. The dissemination of tumor cells in the BM is considered responsible for the further development of the disease followed by metastasis $[19,20]$. Between 20 and $45 \%$ of patients with primary $\mathrm{BC}$ already show single tumor cells in the BM at the first diagnosis: DTCs' detection allows the identification of patients with a high risk of recurrence $[17,18,21]$. The percentage of patients positive for DTCs rises up to $70 \%$ in case of metastasis. In clinical practice, the type of adjuvant therapy can be chosen according to different predictive factors, such as menopausal status, hormonal receptor status, and/or overexpression of the human epidermal growth factor receptor 2 (HER2) on the primary tumor. HER2 overexpression is detected in almost $30 \%$ of all $\mathrm{BC}$ cases, and it has been linked to a more aggressive form of the disease, a strong resistance to chemotherapy, a higher risk of recurrence, and a shorter life expectation. The clinical importance of HER2 has emerged once HER2-targeted agents, such as Trastuzumab, Lapatinib, and Pertuzumab, have been made available [22-24]. Usually, HER2positive BC patients receive an adjuvant therapy combined with HER2-targeted agents when overexpression or gene amplification is found in the primary tumor. The HER2 status of DTCs is usually taken into account, assuming that the two cellular types (i.e. DTCs and cells of the primary tumor) are immunophenotypically identical. However, the HER2 status of DTCs has been shown to be sometimes different from the primary tumor, with a discrepancy between the primary tumor and DTCs of up to $20 \%$ [25-27]. Importantly, patients with a HER2- negative primary tumor are not treated with HER2-targeted agents, although DTCs could be HER2 positive and therefore representing a potential target for tailored treatment options. The aim of this study was to analyze CK-positive DTCs for HER2 gene amplification in BM aspirates from a large cohort of BC patients to monitor any correspondence between the primary tumor and DTCs with respect to the HER2 status and different clinical parameters.

\section{Material and Methods}

\section{Patients}

A total of 156 BC patients from the Department of Gynecology and Obstetrics, Ludwig-Maximilians-University (Munich, Germany) were included in this retrospective study (online suppl. table 1; see www.karger.com/doi/10.1159/000442986 for all online suppl. material). All patients were treated between 1995 and 2007 and had histologically confirmed BC according to standard clinical guidelines. A total of $252 \mathrm{BM}$ aspirates were sampled after written informed consent was obtained. All protocols were approved by the local ethics commission and complied the Declaration of Helsinki guidelines [28]. Tumor classification was done according to the TNM guidelines [29]. The HER2 status of the primary tumors was determined immunohistochemically (HercepTest ${ }^{\circledR}$; DAKO, Denmark), and according to the staining intensity, it was scored on a $0+$ to $3+$ scale. Tumors with a score of $3+$ were classified as HER2 positive, and those with a score of $2+$ were further analyzed by fluorescence in situ hybridization (Inform ${ }^{\circledR}$ HER-2 Kit; Ventana Medical System Inc., USA, and PathVysion Kit; Abbott Molecular, USA). Specimens were classified as HER2 positive when at least 6 intranuclear signals per cell were detected or showed HER2 and chromosome 17 signal ratios $\geq 2$, respectively.

\section{BM Isolation and Cytospins Preparation}

Approximately $5 \mathrm{ml}$ of BM aspirate were collected from both upper anterior iliac crests into EDTA-treated tubes before surgery and immediately processed. Aspirate was washed in Hanks buffer (Biochrom AG, Germany) and centrifuged at $900 \mathrm{rpm}$ for $10 \mathrm{~min}$ at $10^{\circ} \mathrm{C}$ to pellet the cellular fraction. Supernatant was discarded and cell pellet was then separated on a Ficoll-Hypaque density gradient $(1.077 \mathrm{~g} / \mathrm{mol})$ (Pharmacia, Germany). Mononuclear cells were collected from the interphase layer, counted and spun down at $150 \mathrm{~g}$ for $5 \mathrm{~min}$ at room temperature $(\mathrm{RT})$ on a glass slide $(1 \times$ $10^{6}$ cells/spot) (SuperFrost ${ }^{\circledR}$ Plus; Thermo Scientific). Cytospins were dried for $12-24 \mathrm{~h}$ at RT and then immediately stained or stored at $-80^{\circ} \mathrm{C}$.

\section{APAAP Staining and DTC Identification}

Detection of tumor cells in the cytospin preparation was performed as described previously, using the alkaline phosphatase anti-alkaline phosphatase technique (APAAP; DakoCtyomation, Denmark) [30-32]. The murine antibody clone MOPC21 (Sigma, Germany) was used as IgG1 isotype-negative control to test the antibody reaction specificity (data not shown). For each patient, 2 $\times 10^{6}$ cells were screened manually by bright-field microscopy (Axiophot; Carl Zeiss, Germany). 


\section{CISH Staining and HER2 Detection}

Amplification of the HER2 gene was detected using the chromogenic in situ hybridization (CISH) method performed on all slides showing CK-positive DTCs. The samples were stained using the Zymed SPoT-Light HER2 CISH ${ }^{\mathrm{TM}}$ kit (Zymed $^{\circledR}$ Laboratories, USA), according to the manufacturer's instruction. In brief, DTCs were incubated for $10 \mathrm{~min}$ at $65^{\circ} \mathrm{C}$ with $2 \times$ saline sodium citrate (SSC) buffer, digested with pepsin for $5 \mathrm{~min}$ at $37^{\circ} \mathrm{C}$ and washed twice for $4 \mathrm{~min}$ in Phosphate Buffer Saline (PBS; Biochrom AG, Germany). Cells were then fixed in $4 \%$ paraformaldehyde ( $\mathrm{pH} 7.2$ ) for $2 \mathrm{~min}$ and washed again twice for $4 \mathrm{~min}$ in PBS, dehydrated in three graded ethanol series (70, 96, and 100\%, 2 min each) and air dried for at least $20 \mathrm{~min}$. Cells were then incubated with $70 \%$ formamid/2\% SSC plus 10 drops of $0.2 \mathrm{M} \mathrm{HCl}$ for $90 \mathrm{~s}$ at $68^{\circ} \mathrm{C}$, again dehydrated in three graded ethanol series (70, 96, and 100\%, 2 min each) and finally air dried for at least $20 \mathrm{~min}$. After application of $10 \mu$ of Spot-Light HER 2 DNA probe (Zymed Laboratories, USA), the slides were coverslipped, sealed with rubber cement, incubated for $5 \mathrm{~min}$ at $95^{\circ} \mathrm{C}$ and then stored in a humidified chamber at $37^{\circ} \mathrm{C}$ overnight. The slides were finally washed once in $0.5 \times$ SSC for $5 \mathrm{~min}$ at $72^{\circ} \mathrm{C}, 3$ times in $0.05 \%$ Tween 20 -PBS for 2 min at RT, 3 times in deionized water for $2 \mathrm{~min}$ at RT. Immunodetection was performed using the CISH detection kit (Zymed Laboratories, USA). Chromogenic detection of HER 2 amplification was achieved using a standard bright-field microscope (Axiophot; Carl Zeiss, Germany) with a 40-fold magnification. The HER2 gene was considered amplified when at least 4 intranuclear signals were detected per cell.

\section{Statistical Analysis}

Patients were classified as having a HER2-positive DTC status when at least one HER2-positive DTC was detected. Statistical analysis was performed using the SPSS 15.0 software (SPSS Inc., Chicago, Ill., USA). The $\chi^{2}$ test was used to analyze the correlation between the HER2 status of DTCs and the different patients' clinicopathological characteristics. All p values were two sided. $\mathrm{p}$ values $<0.05$ were considered statistically significant.

\section{Results}

\section{Primary Tumor and Patients' Characterization}

In total, $232 \mathrm{BM}$ aspirates were obtained from $156 \mathrm{BC}$ patients. The median age at the primary diagnosis was 56.5 years (range 33-80). A total of 92 (59\%) patients were diagnosed with primary tumor at an early stage (T1a-c), while $61(39.1 \%)$ at a later stage (T2-T4). Fifty-eight $(37.2 \%)$ patients were node positive ( $\mathrm{pN} 1-3)$, and 86 (55.1\%) were node negative ( $\mathrm{pN} 0)$. Most patients showed G2-G3 grading $(\mathrm{n}=135,86.5 \%)$, while only $15(9.6 \%)$ showed G1 grading. Primary tumors $(\mathrm{n}=151)$ were found to be ER positive $(\mathrm{n}=114,75.5 \%)$ or PR positive $(\mathrm{n}=96$, $63.6 \%)$. Finally, $62(39.7 \%)$ primary tumors $(n=156)$ were classified as HER2 0 and $92(58.9 \%)$ as HER2 $1+$ to $3+$. Forty-one (26.3\%) patients were premenopausal, 112 (71.8\%) postmenopausal and $3(1.9 \%)$ perimenopausal.
Table 1. Detection of HER2 on the primary tumor and DTCs $(\mathrm{n}=$ 89)

$\begin{array}{lc}\text { HER2 status of the primary tumor, } \mathrm{n} \\ \text { Positive } & 17(19.1 \%) \\ \text { Negative } & 72(80.9 \%) \\ \text { Total } & 89 \\ \text { HER2 status of DTCs, } \mathrm{n} & \\ \text { Positive } & 31(34.8 \%) \\ \text { Negative } & 58(65.2 \%) \\ \text { Total } & 89\end{array}$

Table 2. Comparison of the HER2 status between primary tumors and the corresponding DTCs at first diagnosis $(n=89)$

\begin{tabular}{lcll}
\hline HER2 status & \multicolumn{2}{l}{ Primary tumor } & \\
\cline { 2 - 4 } & Positive & Negative & Total \\
\hline DTCs, $\mathrm{n}$ & & & \\
$\quad$ Positive & $10(11.2 \%)$ & $21(23.6 \%)$ & $31(34.8 \%)$ \\
Negative & $7(7.8 \%)$ & $51(57.3 \%)$ & $58(65.2 \%)$ \\
Total & $17(19.1 \%)$ & $72(80.9 \%)$ & $89(100.0 \%)$ \\
\hline
\end{tabular}

All of them underwent surgery: 128 (82.1\%) received conservative surgery, while $28(17.9 \%)$ mastectomy. Concerning the therapeutic regimen, 134 (85.9\%) patients were treated with radiotherapy, $66(42.3 \%)$ with endocrine therapy, 51 (32.7\%) with chemotherapy, 22 (14.1\%) with combined endocrine and chemotherapy, and 17 $(10.9 \%)$ did not receive any treatment. None of the patients was treated with Trastuzumab or any other HER2targeted agent at primary diagnosis. Finally, within the entire patient cohort, only $8(5.1 \%)$ patients presented distant metastasis at the time of first diagnosis and 9 (5.8\%) showed local recurrence at follow-up (online suppl. table 1). The median observation time after primary diagnosis was 20 months (range 6-327).

\section{Detection of the HER2 Status of DTCs and Primary Tumor}

A total of 89 BM samples were found positive for DTCs at the time of first diagnosis (table 1). In 31 (34.8\%) DTCpositive samples at least one HER2-positive DTC was detected, while the remaining 58 (65.2\%) were HER2-negative. In the same sample group, only 17 (19.1\%) primary tumors showed a positive HER2 status, while all others $(\mathrm{n}=72,80.9 \%)$ resulted negative. Comparing the HER2 status of DTCs and the primary tumor, $61(68.5 \%)$ patients showed a concordant HER2 status between prima- 
ry tumors and DTCs, being both HER2-negative ( $\mathrm{n}=51$, $57.3 \%)$ or HER2-positive $(\mathrm{n}=10,11.2 \%)$ (table 2$)$. However, $21(23.6 \%)$ patients presented HER2-negative primary tumors and HER2-positive DTCs, while 7 (7.8\%) HER2-positive primary tumors and HER2-negative DTCs. The correlation between the HER2 status of DTCs and the primary tumor was found statistically significant $(\mathrm{p}=0.021)$.

\section{Correlation between the HER2 Status of \\ Primary Tumor and DTCs in Metastatic and \\ Recurrent Patients}

The HER2 status of DTCs was also analyzed in 6 of the 8 patients found with distant metastases already at the first diagnosis. Four (66.6\%) of them showed a concordant HER2-positive status of DTCs and primary tumor, while 1 patient (16.7\%) a concordant HER2-negative status. One single patient (16.7\%) was found with HER2negative DTCs and a HER2-positive primary tumor. The remaining 2 patients of this subgroup were not analyzed. A significant correlation between the HER2 status of DTCs and the primary tumor in patients with distant metastases could not be found ( $\mathrm{p}=0.118$ ) (online suppl. table 2a). Furthermore, the HER2 status of DTCs was also measured in 6 of the 9 patients positive for local recurrence at follow-up. One (16.7\%) single patient showed a concordant HER2-positive status of DTCs and primary tumor, while $3(50 \%)$ patients a concordant HER2-negative status. Two patients (33.3\%) presented HER2-negative DTCs and a HER2-positive primary tumor. The remaining 3 patients from this subgroup were not analyzable. A significant correlation between the HER2 status of DTCs and the primary tumor in patients with local recurrence could not be found ( $\mathrm{p}=0.27$ ) (online suppl. table $2 b$ ).

\section{Correlation between the HER2 Status of DTCs and Patients' Characteristics}

The DTC-positive cohort $(\mathrm{n}=89)$ was stratified according to the HER2 status of DTCs and the different patients' characteristics. No significant correlation was ever found with primary tumor size $(\mathrm{p}=0.39)$, nodal status $(\mathrm{p}=0.97)$, tumor grading $(\mathrm{p}=0.74)$, menopausal status $(\mathrm{p}=0.40)$, or hormone receptor status $(\mathrm{p}=0.24)$.

\section{Correlation between the HER2 Status of DTCs at Primary Diagnosis and after Chemotherapy}

For 8 patients, BM aspirates were prepared at the time of first diagnosis and immediately after adjuvant chemotherapy. Before therapy, most patients $(n=6,75 \%)$ presented DTC-positive BM. Of these, 2 patients had HER2-positive DTCs, 3 had HER2-negative DTCs and 1 was not analyzable for the HER2 status. Immediately after completion of chemotherapy, the BM of the same 8 patients was analyzed again, and most patients $(n=5$, $62 \%$ ) were still found DTC positive. Notably, the BM of the 2 patients found DTC negative during the first screening, resulted in both cases DTC positive. However, only one of them showed HER2-positive DTCs. Of the 6 patients with DTC-positive BM during the first screening, 3 confirmed their positivity also after the therapy, while the remaining 3 did not have any longer detectable DTCs. Two of the 3 persistently DTC-positive patients showed a HER2 status in agreement with the first finding. For the third one, no comparison was possible since no analysis was done at the time of first diagnosis. No significant correlation in the HER2 status was found between DTCs before and after chemotherapy and the corresponding primary tumor $(\mathrm{p}=0.136)$ (online suppl. table 3 ).

\section{Correlation between the HER2 Status of Primary}

Tumor and DTCs before Adjuvant Therapy and at Follow-Up

Eighteen patients underwent a double BM collection, before treatment and at follow-up, in average 14.9 months after the first collection. None of the patients showed local recurrence. Thirteen $(72.2 \%)$ patients presented DTCs at the time of the first diagnosis: of these, 7 (70\%) were HER2-negative and 3 (30\%) HER2-positive. Three samples were not analyzable. At follow-up, 6 (33.3\%) patients resulted positive for DTCs: of these, $4(66.7 \%)$ were found HER2-positive and 2 (33.33\%) HER2-negative. In all cases but one, the HER2 status at primary diagnosis and follow-up was concordant. Nevertheless, no significant correlation between the HER2 status of DTCs and the primary tumor was found ( $p=0.49$ at the time of the first collection; $\mathrm{p}=0.54$ at the time of the second collection) (online suppl. table 4).

\section{Discussion}

The detection of DTCs in BM of BC patients after surgery and first line of therapy is correlated to an early and more aggressive recurrence, followed by a shorter survival $[33,34]$. Unfortunately, most DTCs are insensible to common adjuvant chemotherapy regimens, which targets only proliferating tumor cells $[35,36]$. The validity of HER2-targeted agents on the therapeutic treatment of 
MRD has been already proposed [24, 27, 32]. However, in clinical practice, only primary tumor specimens are routinely checked for HER2 status and patients receive anti-HER2-based treatment depending only on these results. Therapies are decided on the hypothesis that MRD presents the same characteristics as the primary tumor, despite the fact that there is increasing evidence of the contrary $[26,37,38]$. As a consequence, patients diagnosed with a HER2-negative primary tumor do not receive HER2-targeted agents, and cannot benefit of this treatment in case DTCs are instead HER2-positive. In order to gain more insight into the significance of any correlation between the HER2 status of DTCs isolated from $\mathrm{BM}$ of $\mathrm{BC}$ patients and the corresponding primary tumors, we compared the HER2 status of DTCs with the primary tumors and other parameters such as patient's characteristics, systemic therapy, presence of local recurrence or metastasis, unraveling heterogeneity in the HER2 status. DTCs were detected in 89 BM samples collected from the 156 patients included in the study with a HER 2 positivity rate of $34.8 \%(n=31)$. Screening the same 89 patients with respect to the HER2 status of the primary tumor, only 17 (19.1\%) were found positive. Comparing the results and correlating the HER2 status of DTCs and primary tumors, most of the patients $(\mathrm{n}=61$, 68.5\%) had a correspondent HER2 status. Interestingly, in the remaining 28 (31.4\%) patients, a significant correlation with respect to the HER2 status between the primary tumor and the DTCs was found $(\mathrm{p}=0.021): 7(7.8 \%)$ patients with HER2-positive primary tumors showed still HER2-negative DTCs, while 21 (23.6\%) patients with HER2-negative primary tumor presented HER2-positive DTCs $(p=0.021)$. No significant correlation was found between the HER2 status of DTCs and primary tumor with respect to primary tumor size $(\mathrm{p}=0.39)$, nodal status $(\mathrm{p}=0.97)$, tumor grading $(\mathrm{p}=0.74)$, menopausal status $(\mathrm{p}=0.40)$ or hormone receptor status $(\mathrm{p}=0.24)$. In addition, no significant correlation was found with respect to local recurrence $(p=0.27)$, metastasis $(p=0.118)$ or chemotherapy $(\mathrm{p}=0.136)$. This study presented some limitations, such as the retrospective sampling and the heterogeneous patient cohort, not treated according to the actual guidelines; however, the results are clinically relevant. Immunophenotyping changes can be connected to CTCs' and DTCs' intravasation and secondary tissue colonization [39]. Discrepancies in the HER2 status between primary tumor and metastasis have been already described $[32,40-43]$. Several studies underlined a discrepancy also between primary tumors and CTCs both in early and metastatic BC patients [44-46]. In this study, a clear dis- cordance was found between primary tumor and DTCs. The acquisition of HER2 amplification in DTCs, while the primary tumor is negative, can be explained with a selective advantage conferred by HER2 to DTCs during dissemination $[21,25,47-50]$, or with a higher tendency of the HER2-positive DTC clones to detach from the primary tumor and to spread [25,48-52]. We found that $23.6 \%$ of patients presented a HER2-negative primary tumor and HER2-positive DTCs. For patients' management, this finding is clinically relevant, since this patients' group was not treated with HER2-targeted agents, although they could have benefit from the therapy due to the HER2 positive status of the DTCs. In the latest years, the use of HER2-targeting agents has raised much interest to treat not only primary tumors but also CTCs/DTCs. Trastuzumab has been already shown to target chemotherapy-resistant cytokeratin-positive cells in the peripheral blood and BM of patients with BC [53]. In addition, several clinical trials such as the German multicenter study Detect III (NCT01619111) and the European multicenter study TreatCTC (NCT01548677) are already focusing on the clinical impact of Lapatinib and Trastuzumab on BC patients presenting CTCs [54]. Interestingly, we found that $7.8 \%$ of the patients were HER2-positive on primary tumor and negative on DTCs. Detection of HER2-negative DTCs in BM with corresponding HER2-positive primary tumors is difficult to rationalize. Loss of the phenotype could be linked to the selective pressure given by the therapy. However, in this case, the sampling was performed before adjuvant therapy; therefore, the shift in the phenotype was independent of the treatment. More studies should be performed to exclude any sampling error and to rationalize these findings.

\section{Conclusion}

This study showed a significant grade of discordance in the HER2 status between primary tumors and DTCs as found in the enrolled patient cohort. Importantly, a relevant number of originally HER2-negative patients presented HER2-positive DTCs. Amplification of the HER2 gene in persisting DTCs could be a valid method to stratify patients for a better personalized treatment. In particular, patient stratification for new targeted agents against HER2, such as specific antibodies, could be considered as an individualized treatment option even for those patients who present HER2-negative primary tumors but nevertheless HER2-positive DTCs. 


\section{Acknowledgements}

The authors wish to thank Alvera Rengel Puertas and Beate Zill (Ludwig-Maximilians-University, Munich) for their technical assistance and the patients who participated in this study.

\section{Disclosure Statement}

The authors have no conflicts of interest to disclose.

\section{References}

1 Glendenning J, Cook G: Imaging breast cancer bone metastases: current status and future directions. Semin Nucl Med 2013;43:317323.

-2 Ferlay J, Shin HR, Bray F, Forman D, Mathers C, Parkin DM: Estimates of worldwide burden of cancer in 2008: GLOBOCAN 2008. Int J Cancer 2010;127:2893-2917.

-3 Cote RJ, Rosen PP, Lesser ML, Old LJ, Osborne MP: Prediction of early relapse in patients with operable breast cancer by detection of occult bone marrow micrometastases. J Clin Oncol 1991;9:1749-1756.

-4 Diel IJ, Kaufmann M, Costa SD, Holle R, von Minckwitz G, Solomayer EF, Kaul S, Bastert G: Micrometastatic breast cancer cells in bone marrow at primary surgery: prognostic value in comparison with nodal status. J Natl Cancer Inst 1996;88:1652-1658.

$\checkmark 5$ Wei S, Li Y, Siegal GP, Hameed O: Breast carcinomas with isolated bone metastases have different hormone receptor expression profiles than those with metastases to other sites or multiple organs. Ann Diagn Pathol 2011; 15:79-83.

6 Jung SY, Rosenzweig M, Sereika SM, Linkov F, Brufsky A, Weissfeld JL: Factors associated with mortality after breast cancer metastasis. Cancer Causes Control 2012;23:103-112.

7 Tateishi U, Gamez C, Dawood S, Yeung HW, Cristofanilli M, Macapinlac HA: Bone metastases in patients with metastatic breast cancer: morphologic and metabolic monitoring of response to systemic therapy with integrated PET/CT. Radiology 2008;247:189-196.

8 Fass L: Imaging and cancer: a review. Mol Oncol 2008;2:115-152.

9 Alunni-Fabbroni M, Muller V, Fehm T, Janni W, Rack B: Monitoring in metastatic breast cancer: is imaging outdated in the era of circulating tumor cells? Breast Care 2014;9:1621.

10 Schwarz-Dose J, Untch M, Tiling R, Sassen S, Mahner S, Kahlert S, Harbeck N, Lebeau A Brenner W, Schwaiger M, Jaenicke F, Avril N: Monitoring primary systemic therapy of large and locally advanced breast cancer by using sequential positron emission tomography imaging with [18f]fluorodeoxyglucose. J Clin Oncol 2009;27:535-541.

11 Therasse P, Arbuck SG, Eisenhauer EA, Wanders J, Kaplan RS, Rubinstein L, Verweij J, Van Glabbeke M, van Oosterom AT, Chris- tian MC, Gwyther SG: New guidelines to evaluate the response to treatment in solid tumors. European Organization for Research and Treatment of Cancer, National Cancer Institute of the United States, National Cancer Institute of Canada. J Natl Cancer Inst 2000;92:205-216.

12 Eisenhauer EA, Therasse P, Bogaerts J, Schwartz LH, Sargent D, Ford R, Dancey J, Arbuck S, Gwyther S, Mooney M, Rubinstein L, Shankar L, Dodd L, Kaplan R, Lacombe D, Verweij J: New response evaluation criteria in solid tumours: revised RECIST guideline (version 1.1). Eur J Cancer 2009;45:228-247.

13 Alix-Panabieres C, Pantel K: Circulating tumor cells: liquid biopsy of cancer. Clin Chem 2013;59:110-118.

14 Pantel K, Brakenhoff RH, Brandt B: Detection, clinical relevance and specific biological properties of disseminating tumour cells. Nat Rev Cancer 2008;8:329-340.

15 Joosse SA, Gorges TM, Pantel K: Biology, detection, and clinical implications of circulating tumor cells. EMBO Mol Med 2014;7:1-11.

16 Cristofanilli M, Budd GT, Ellis MJ, Stopeck A, Matera J, Miller MC, Reuben JM, Doyle GV, Allard WJ, Terstappen LW, Hayes DF: Circulating tumor cells, disease progression, and survival in metastatic breast cancer. N Engl J Med 2004;351:781-791.

17 Braun S, Vogl FD, Naume B, Janni W, Osborne MP, Coombes RC, Schlimok G, Diel IJ, Gerber B, Gebauer G, Pierga JY, Marth C, Oruzio D, Wiedswang G, Solomayer EF, Kundt G, Strobl B, Fehm T, Wong GY, Bliss J, Vincent-Salomon A, Pantel K: A pooled analysis of bone marrow micrometastasis in breast cancer. N Engl J Med 2005;353:793802.

18 Janni W, Vogl FD, Wiedswang G, Synnestvedt $\mathrm{M}$, Fehm T, Juckstock J, Borgen E, Rack B, Braun S, Sommer H, Solomayer E, Pantel K, Nesland J, Friese K, Naume B: Persistence of disseminated tumor cells in the bone marrow of breast cancer patients predicts increased risk for relapse - a European pooled analysis. Clin Cancer Res 2011;17:2967-2976.

19 Pantel K, Alix-Panabieres C, Riethdorf S: Cancer micrometastases. Nat Rev Clin Oncol 2009;6:339-351.

20 Braun S, Pantel K, Muller P, Janni W, Hepp F, Kentenich CR, Gastroph S, Wischnik A,
Dimpfl T, Kindermann G, Riethmuller G, Schlimok G: Cytokeratin-positive cells in the bone marrow and survival of patients with stage I, II, or III breast cancer. N Engl J Med 2000;342:525-533.

21 Hartkopf AD, Banys M, Meier-Stiegen F, Hahn M, Rohm C, Hoffmann J, Helms G, Taran FA, Wallwiener M, Walter C, Neubauer H, Wallwiener D, Fehm T: The HER2 status of disseminated tumor cells in the bone marrow of early breast cancer patients is independent from primary tumor and predicts higher risk of relapse. Breast Cancer Res Treat 2013;138:509-517.

22 Medina PJ, Goodin S: Lapatinib: A dual inhibitor of human epidermal growth factor receptor tyrosine kinases. Clin Ther 2008;30: 1426-1447.

23 Huang Z, Brdlik C, Jin P, Shepard HM: A panHER approach for cancer therapy: background, current status and future development. Expert Opin Biol Ther 2009;9:97-110.

24 Krawczyk N, Banys M, Neubauer H, Solomayer EF, Gall C, Hahn M, Becker S, Bachmann R, Wallwiener D, Fehm T: HER2 status on persistent disseminated tumor cells after adjuvant therapy may differ from initial HER2 status on primary tumor. Anticancer Res 2009;29:4019-4024.

-25 Solomayer EF, Becker S, Pergola-Becker G Bachmann R, Kramer B, Vogel U, Neubauer H, Wallwiener D, Huober J, Fehm TN: Comparison of HER2 status between primary tumor and disseminated tumor cells in primary breast cancer patients. Breast Cancer Res Treat 2006;98:179-184.

26 Becker S, Becker-Pergola G, Fehm T, Wallwiener D, Solomayer EF: HER2 expression on disseminated tumor cells from bone marrow of breast cancer patients. Anticancer Res 2005;25:2171-2175.

27 Fehm T, Becker S, Duerr-Stoerzer S, Sotlar K, Mueller V, Wallwiener D, Lane N, Solomayer E, Uhr J: Determination of HER2 status using both serum HER2 levels and circulating tumor cells in patients with recurrent breast cancer whose primary tumor was HER2 negative or of unknown HER2 status. Breast Cancer Res 2007;9:R74.

28 World Medical Association: World Medical Association Declaration of Helsinki: ethical principles for medical research involving human subjects. JAMA 2013;310:2191-2194. 
-29 Singletary SE, Allred C, Ashley P, Bassett LW, Berry D, Bland KI, Borgen PI, Clark G, Edge SB, Hayes DF, Hughes LL, Hutter RV, Morrow M, Page DL, Recht A, Theriault RL, Thor A, Weaver DL, Wieand HS, Greene FL: Revision of the American Joint Committee on Cancer staging system for breast cancer. J Clin Oncol 2002;20:3628-3636.

-30 Schindlbeck C, Pfab G, Jueckstock J, Andergassen U, Sommer H, Janni W, Friese K, Rack B: Prognostic relevance of disseminated tumor cells in the bone marrow of patients with primary breast cancer - results of a standardized follow-up. Anticancer Res 2011;31: 2749-2755.

- 31 Stigbrand T, Andres C, Bellanger L, Bishr Omary M, Bodenmuller H, Bonfrer H, Brundell J, Einarsson R, Erlandsson A, Johansson A, Leca JF, Levi M, Meier T, Nap M, Nustad K, Seguin P, Sjodin A, Sundstrom B, van Dalen A, Wiebelhaus E, Wiklund B, Arlestig L, Hilgers J: Epitope specificity of 30 monoclonal antibodies against cytokeratin antigens: the ISOBM TD5-1 Workshop. Tumour Biol 1998;19:132-152.

- 32 Rack B, Juckstock J, Gunthner-Biller M, Andergassen U, Neugebauer J, Hepp P, Schoberth A, Mayr D, Zwingers T, Schindlbeck C, Friese K, Janni W: Trastuzumab clears HER2/neupositive isolated tumor cells from bone marrow in primary breast cancer patients. Arch Gynecol Obstet 2012;285:485-492.

- 33 Janni W, Rack B, Schindlbeck C, Strobl B, Rjosk D, Braun S, Sommer H, Pantel K, Gerber B, Friese K: The persistence of isolated tumor cells in bone marrow from patients with breast carcinoma predicts an increased risk for recurrence. Cancer 2005; 103:884-891.

- 34 Wiedswang G, Borgen E, Karesen R, Qvist H, Janbu J, Kvalheim G, Nesland JM, Naume B: Isolated tumor cells in bone marrow three years after diagnosis in disease-free breast cancer patients predict unfavorable clinical outcome. Clin Cancer Res 2004;10:5342-5348.

- 35 Meng S, Tripathy D, Frenkel EP, Shete S, Naftalis EZ, Huth JF, Beitsch PD, Leitch M, Hoover S, Euhus D, Haley B, Morrison L, Fleming TP, Herlyn D, Terstappen LW, Fehm T, Tucker TF, Lane N, Wang J, Uhr JW: Circulating tumor cells in patients with breast cancer dormancy. Clin Cancer Res 2004; 10 : 8152-8162.

36 Muller V, Stahmann N, Riethdorf S, Rau T, Zabel T, Goetz A, Janicke F, Pantel K: Circulating tumor cells in breast cancer: correlation to bone marrow micrometastases, heterogeneous response to systemic therapy and low proliferative activity. Clin Cancer Res 2005; 11:3678-3685.
37 Gancberg D, Di Leo A, Cardoso F, Rouas G, Pedrocchi M, Paesmans M, Verhest A, Bernard-Marty C, Piccart MJ, Larsimont D: Comparison of HER-2 status between primary breast cancer and corresponding distant metastatic sites. Ann Oncol 2002;13:10361043 .

38 Aktas B, Muller V, Tewes M, Zeitz J, KasimirBauer S, Loehberg CR, Rack B, Schneeweiss A, Fehm T: Comparison of estrogen and progesterone receptor status of circulating tumor cells and the primary tumor in metastatic breast cancer patients. Gynecol Oncol 2011; 122:356-360

-39 Chambers AF, Naumov GN, Vantyghem SA, Tuck AB: Molecular biology of breast cancer metastasis. Clinical implications of experimental studies on metastatic inefficiency. Breast Cancer Res 2000;2:400-407.

-40 Santinelli A, Pisa E, Stramazzotti D, Fabris G: HER-2 status discrepancy between primary breast cancer and metastatic sites. Impact on target therapy. Int J Cancer 2008;122:9991004.

-41 Simmons C, Miller N, Geddie W, Gianfelice D, Oldfield M, Dranitsaris G, Clemons MJ: Does confirmatory tumor biopsy alter the management of breast cancer patients with distant metastases? Ann Oncol 2009;20: 1499-1504.

42 Lindstrom LS, Karlsson E, Wilking UM, Johansson U, Hartman J, Lidbrink EK, Hatschek T, Skoog L, Bergh J: Clinically used breast cancer markers such as estrogen receptor, progesterone receptor, and human epidermal growth factor receptor 2 are unstable throughout tumor progression. J Clin Oncol 2012;30: 2601-2608.

43 Yonemori K, Tsuta K, Shimizu C, Hatanaka Y, Hashizume K, Ono M, Nakanishi Y, Hasegawa T, Miyakita Y, Narita Y, Shibui S, Fujiwara Y: Immunohistochemical profiles of brain metastases from breast cancer. J Neurooncol 2008;90:223-228.

44 Castle J, Shaker H, Morris K, Tugwood JD, Kirwan CC: The significance of circulating tumour cells in breast cancer: a review. Breast 2014;23:552-560.

45 Navin N, Kendall J, Troge J, Andrews P, Rodgers L, McIndoo J, Cook K, Stepansky A, Levy D, Esposito D, Muthuswamy L, Krasnitz A, McCombie WR, Hicks J, Wigler M: Tumour evolution inferred by single-cell sequencing. Nature 2011;472:90-94.

-46 Magbanua MJ, Sosa EV, Roy R, Eisenbud LE, Scott JH, Olshen A, Pinkel D, Rugo HS, Park JW: Genomic profiling of isolated circulating tumor cells from metastatic breast cancer patients. Cancer Res 2013;73:30-40.
47 Lang JE, Mosalpuria K, Cristofanilli M, Krishnamurthy S, Reuben J, Singh B, Bedrosian I, Meric-Bernstam F, Lucci A: HER2 status predicts the presence of circulating tumor cells in patients with operable breast cancer. Breast Cancer Res Treat 2009;113:501-507.

48 Fehm T, Muller V, Aktas B, Janni W, Schneeweiss A, Stickeler E, Lattrich C, Lohberg CR, Solomayer E, Rack B, Riethdorf S, Klein C, Schindlbeck C, Brocker K, Kasimir-Bauer S, Wallwiener D, Pantel K: HER2 status of circulating tumor cells in patients with metastatic breast cancer: a prospective, multicenter trial. Breast Cancer Res Treat 2010;124:403412.

49 Meng S, Tripathy D, Shete S, Ashfaq R, Haley B, Perkins S, Beitsch P, Khan A, Euhus D, Osborne C, Frenkel E, Hoover S, Leitch M, Clifford E, Vitetta E, Morrison L, Herlyn D, Terstappen LW, Fleming T, Fehm T, Tucker T, Lane N, Wang J, Uhr J: HER-2 gene amplification can be acquired as breast cancer progresses. Proc Natl Acad Sci USA 2004;101: 9393-9398.

50 Hayes DF, Walker TM, Singh B, Vitetta ES, Uhr JW, Gross S, Rao C, Doyle GV, Terstappen LW: Monitoring expression of HER-2 on circulating epithelial cells in patients with advanced breast cancer. Int J Oncol 2002;21: 1111-1117.

51 Pestrin M, Bessi S, Galardi F, Truglia M, Biggeri A, Biagioni C, Cappadona S, Biganzoli L, Giannini A, Di Leo A: Correlation of HER2 status between primary tumors and corresponding circulating tumor cells in advanced breast cancer patients. Breast Cancer Res Treat 2009;118:523-530.

52 Wulfing P, Borchard J, Buerger H, Heidl S, Zanker KS, Kiesel L, Brandt B: HER2-positive circulating tumor cells indicate poor clinical outcome in stage I to III breast cancer patients. Clin Cancer Res 2006;12:1715-1720.

53 Bozionellou V, Mavroudis D, Perraki M, Papadopoulos S, Apostolaki S, Stathopoulos E, Stathopoulou A, Lianidou E, Georgoulias V: Trastuzumab administration can effectively target chemotherapy-resistant cytokeratin-19 messenger RNA-positive tumor cells in the peripheral blood and bone marrow of patients with breast cancer. Clin Cancer Res 2004;10: 8185-8194.

54 Bidard FC, Fehm T, Ignatiadis M, Smerage JB, Alix-Panabieres C, Janni W, Messina C, Paoletti C, Muller V, Hayes DF, Piccart M, Pierga JY: Clinical application of circulating tumor cells in breast cancer: overview of the current interventional trials. Cancer Metastasis Rev 2013;32:179-188. 